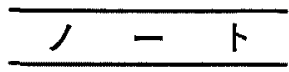

「農化 第 40 巻，第 11 号, p. 429 430, 1966]

アリルベンゼンの無水塩化アルミニウム 存在下に斿る重合反応

丹羽栄二*, 青木博夫, 田中 博, 故田村悌一

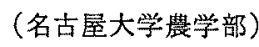

昭和 41 年 2 月 14 日受理

\title{
Polymerization of Allylbenzene in the Presence of Aluminum Chloride (Note)
}

By Eiji Niwa, Hiroo AoKI, Hiroshi TANAKa and the late Teiichi TAmUra

Faculty of Agriculture, Nagoya University

\begin{abstract}
Allylbenzene polymerized in the presence of aluminum chloride in nitrobenzene at $0^{\circ} \mathrm{C}$ From reaction mixture two dimers $\left[(I)\right.$, b. p. $112 \sim 3^{\circ} \mathrm{C} / 0.01 \mathrm{mmHg}, \lambda_{\max }^{\mathrm{CHCl}_{3}} 260,270 \mathrm{~m} \mu$ $(\log \varepsilon 2.9,2.8)$; (II), b. p. $\left.148^{\circ} \mathrm{C} / 0.01 \mathrm{mmHg}, \lambda_{\max }^{\mathrm{CHCl}_{3}} 256,270 \mathrm{~m} \mu(\log \varepsilon 3.2,2.9)\right]$ and a trimer [(III), b. p. $182^{\circ} \mathrm{C} / 0.1 \mathrm{mmHg}, \lambda_{\max }^{\mathrm{CHOl}_{3}} 258 \mathrm{~m} \mu$ ( $\left.\left.\log \varepsilon 3.8\right)\right]$ were isolated by fractional distillation. Zinc dust distillation of (I) and (II) gave 1-phenylnaphthalene and 2-phenylnaphthalene, respectively. By this fact along with NMR-[(I), $\tau=9.1(3 \mathrm{H}$, triplet, $J=6.8$ c.p.s. $), \tau=6.0(1 \mathrm{H}$, triplet, $J=6.7$ c.p.s. $)$; (II $), \tau=9.0(3 \mathrm{H}$, triplet, $J=6.8$ c.p.s. $)]$

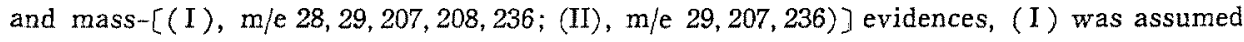
to be 1-ethyl-4-phenyl-1,2,3,4-tetrahydronaphthalene and (II) to be 1-ethyl-2-phenyl-1, 2, 3,4-tetrahydronaphthalene.

(Received February 14, 1966)
\end{abstract}

\section{1. 緒言}

1957 年 J. C. Abrahamse ら(1)は, アリルペンゼンを ケイタンダステン酸をたは無水塩化アルミニウム触媒下 で重合させ，それそれれ3ないし4量体と考古られる物質 を得, それらの水素添加物について各種の物理定数を測 定したが，その化学構造については詳しく述べていな W.

筆者らは，無水塩化アルミニウムを触媒としてニトロ ベンゼン溶液でこの重合反応を試み，反応生成物を検討 したところ，その大部分は高度の減圧下でる蒸溜されず 高分子量の重合体と考光られるものであったが，ごく少 量の物質は蒸溜される比較的低分子量のるのであった。 この蒸溜で得られる物質は，要す元素分析および分子量 測定等からアリルベンゼンの低重合体であり，その 3 種 の存在が翀められたので、これらの物質が高重合反応の * 現在 : 三重其立大学水産学部
中間段階の生成物であるならば巨大分子への生長過程の 解明役立つである 5 々考点，つづいて化学構造を検討 した，結果的には高重合反応の中間生成物といらよりは 別の二量体执よび三量体であったが概要を報告する。

\section{2. 実験および結果}

\section{2-1. アリルベンゼンの重合}

無水塩化アルミニウム $36 \mathrm{~g}(0.27 \mathrm{M})$ をニトロペンゼ ン $50 \mathrm{ml}$ に䀣濁させ $-10^{\circ}$ に冷却し, アリルベンゼン 32 $\mathrm{g}(0.27 \mathrm{M})$ をこトロベンゼン $30 \mathrm{ml}$ に溶解した液を靦䢁 しつつ滴下する，この際反応温度は $0^{\circ}$ を越点ないよ5 飞注意する(滴下時間約 30 分).

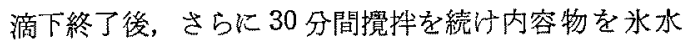
$200 \mathrm{ml}$ に投ずる. ニトロベンゼン層を水蒸気蒸溜に付 し溶某就よび未反応のアリルベンゼンを除去し残海を酸 酸エチル $100 \mathrm{ml}$ に転溶する. $10 \%$ 塩酸で 3 回洗涤し, 無水硫酸ナトリウムで脱水する，溶媒を溜去した後, 高 
第1表 フリルベンゼン重合体の諸性筫

\begin{tabular}{|c|c|c|c|c|c|c|c|}
\hline & \multirow{2}{*}{$\begin{array}{r}\text { 沸 } \\
\left({ }^{\circ} \mathrm{C} / \times 10^{-3}\right. \\
\mathrm{mmHg})\end{array}$} & \multirow{2}{*}{$\begin{array}{l}\text { 收量 } \\
(\mathrm{g})\end{array}$} & \multicolumn{2}{|c|}{ 元萦分析値 } & \multicolumn{2}{|c|}{ 分子 量 } & \multirow{2}{*}{$\begin{array}{c}\text { 紫外線吸収スペクトル } \\
\lambda_{\max }^{\mathrm{CHCl}} \operatorname{m} \mu(\log \varepsilon)\end{array}$} \\
\hline & & & $\mathrm{C} \%$ & $\mathrm{H} \%$ & $\begin{array}{l}\text { シスト法 } \\
\text { (カンファー) }\end{array}$ & $\begin{array}{l}\text { 䓄量 } \\
\text { 分析 }\end{array}$ & \\
\hline Fr. I I & $112 \sim 3 / 10$ & 3.0 & 91.60 & 8.67 & 231 & 236 & $260(2.9), 270(2.8)$ \\
\hline II & $148 / 10$ & 0.8 & 91.75 & 8. 27 & 243 & 236 & $256(3.2), 270(2.9)$ \\
\hline III & $182 \sim 4 / 100$ & 0.8 & 91.58 & 8.26 & 353 & 354 & $258(3.8)$ \\
\hline $\begin{array}{l}\text { アリルベンゼン } \\
\text { (計算值) }\end{array}$ & & & 91.47 & 8.53 & 11 & & \\
\hline
\end{tabular}

真空で蒸溜し 3 個の揮発性成分を得た。な打蒸溜残渣と して約 $25 \mathrm{~g}$ の茶褐色粘稠性液体が得られたが，この物質 はさらに重合の進んだものと考えられる。

またる個の蒸溜物をそれぞれさらに精溜した結果，第 I表に示卞粘稠な溃光性液体 (Fr. I， II，III) を得た。

第1表に示した分子量よりFr. I，IIはアリルベンゼ ンの 2 量体であり，Fr. III は 3 量体であることは明らか である。

\section{2-2. 重合体の吸収スペクトル}

赤外線吸收スペクトルではI，II，III ともに690，740 $\mathrm{cm}^{-1}$ に強い吸収を持ち, ベンゼン核の mono-置換体の 存在を示し，1,380,2,900 $\mathrm{cm}^{-1}$ の吸収はメチル基の存 在を示唆する。なお Fr. III は $3,020 \mathrm{~cm}^{-1}$ に鋭いピーク を持ち 2 重結合のレ として測定). 紫外線吸収スペクトルでFr. I, II の 270 $\mathrm{m} \mu$ の吸収は鋭く，キシレンまたは $1,2,3,4$-テトラヒド ロナフタリンの吸収に類似する。

\section{2-3. 重合体の亜鉛末乾溜}

各Fr.を常法により再鉛末乾溜を行ない，それぞれの 溜分をアルミナカラムで精製した結果, Fr.Iより】ーフェ ニルナフタリン [m. p. $45^{\circ} ; \lambda_{\max }^{\text {hexane }} 230 \mathrm{~m} \mu(\log \varepsilon 4.8)$, $288 \mathrm{~m} \mu(\log \varepsilon 3.9])$; 文献値 $\left[\mathrm{m}\right.$. p. $45^{\circ}(2) ; \lambda_{\mathrm{max}}^{\text {eyclohexane }}$ $\left.227 \mathrm{~m} \mu(\log \varepsilon 4.8), 288 \mathrm{~m} \mu(\log \varepsilon 4.0)^{3}\right]$, Fr. II $上 り$ $2 ー フ ェ ニ ル ナ フ タ リ ン ~\left(m, ~ p . ~ 102^{\circ} ; \lambda_{\max }^{\mathrm{hexane}} 250 \mathrm{~m} \mu(\log \right.$ $\varepsilon 4.8), 290 \mathrm{~m} \mu(\log \varepsilon 4.0)]$; 文献值 [m. p. 104 ${ }^{\circ}(2)$; $\lambda_{\max }^{\text {eyclohexane }} 250 \mathrm{~m} \mu(\log \varepsilon 4.7), 288 \mathrm{~m} \mu(4.0)^{(3)}$ ] が得ら れた。な括 Fr. III からは構造不明の液体が微量得られ た.

亜鉛末乾溜の結果より，Fr.Iには 1-フェニル-1, 2, 3, 4-テトラとドロナフタリン, Fr. II には 2-フェニル-1, 2,3,4-テトラヒドロナフタリンの存在が推定される.

\section{2-4. 核磁気垬鳴吸収および質量分析}

四塩化炭素溶液 (60mc, T.M.S. 内部標準) で Fr. I
は99.1 (いずれも $\tau$ 值, $3 \mathrm{H}$, triplet, $J=6.8$ c.p.s.), $6.0(1 \mathrm{H}$, triplet, $J=6.7)$, Fr. II $49.0(3 \mathrm{H}$, triplet, $J=6.8$ をを示し，いずれのFr.にも各々 1 個のエチル基 の存在が推定される. また特に Fr. I には 2 個のフェニ ル基に挾まれたメチン水素が 1 個存在し，これに水素原 子 2 個が隣接していることが明らかである。

以上の実駼結果から Fr. I は，1-エチルー4-フェニルー 1, 2,3,4-テトラヒドロナフタリンであり, Fr. II は，1エチルー2-フェニル-1, 2,3,4-テトラヒドロ+フタリンで めると考えられる。

また質量分析により得られたスベクトル（Fr. I， m/e 28, 29, 207，208, 236 ; Fr. II, m/e 29，207，236) は， 推定棈造式（第 1 图）によってよく理解される.

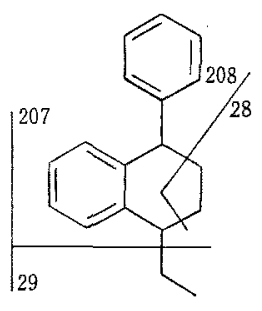

Fr. I

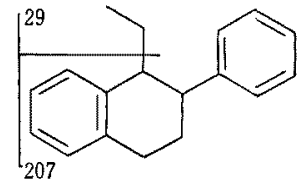

Fr. II
第 1 図 Fr. I, II の措定構造式

（数值は質量分析のフラグメントピーク）

終りに有益な御助言定いただいた名古屋大学農学部 加藤夏樹氏叔よび元素分析を担当された浜地三恵子孃， 中根紀代子釟に深謝します。

な和この報告の大要は, 昭和 38 年 5 月，日本農芸化 学会中部支部第 34 回例会に括いて発表した。

(1) J. C. Abrahamse et al. : Brennstoff-Chem., 38, 187 (1957).

(2) I. Heilbron et al. : "Dictionary of Organic Compounds", Oxford Uuiv. Press (1953).

(3) A.F. Robert et al. : "Ultraviolet Spectra of Aromatic Compounds", John Wiley \& Sons, New York (1951). 